\title{
Oral health-related quality of life among older patients treated with complete prostheses
}

\author{
Jakość życia związana ze zdrowiem jamy ustnej wśród pacjentów \\ użytkujących protezy całkowite
}

\author{
Gerostomatology Clinic, Poznan University of Medical Sciences, Poland
}

DOI: http://dx.doi.org/10.20883/df.2016.1

\begin{abstract}
Introduction. Prosthetic rehabilitation of edentulous patients exerts an indisputable influence on their sense of oral health-related quality of life (OHRQoL). This study examines which particular OHRQoL aspects pose the biggest challenge in terms of improvement upon the conclusion of a complete prosthesis adaptation period.

Basic research design. Patients were examined at the Gerostomatology Clinic, Poznań University of Medical Sciences, in 2012-2013.

Participants. The research involved 76 edentulous people over 60 years of age, of whom 66 returned for post-treatment check-ups after three months.

Interventions. Oral health-related quality of life was examined, using the General Oral Health Assessment Index, prior to prosthetic restoration and following a three-month adaptation period.

Results. Within the scope of an OHRQoL assessment, the examined patients scored the fewest points with regard to problems caused by mastication (Q2), unease at the appearance of their dentition (Q9), and discomfort experienced while eating (Q5). Following the three-month adaptation period, the highest percentage increase was observed in terms of the patient's satisfaction with the looks of their dentition (Q7), while more than $10 \%$ of the patients experienced the negative impact of eating-related problems on their daily lives (Q1, Q2, Q5).

Conclusions. Prosthetic treatment of edentulous patients using conventional complete prostheses significantly improves patients' oral health-related quality of life. Discomfort caused by problems with mastication can be observed among $10 \%$ of the examined patients.
\end{abstract}

Keywords: oral health-related quality of life, elders, prosthetic treatment, edentulism.

\section{Streszczenie}

Wstęp. Rehabilitacja protetyczna pacjentów bezzębnych ma niekwestionowany wpływ na poczucie jakości życia związanej ze zdrowiem jamy ustnej (OHRQoL). W pracy tej przeanalizowano, w których dokładnie aspektach OHQRoL najtrudniej osiągnąć poprawę po okresie adaptacji do nowych protez całkowitych.

Materiał i metody. Badanie pacjentów zostało przeprowadzone w Klinice Gerostomatologii Uniwersytetu Medycznego w Poznaniu w latach 2012-2013. W badaniu wzięło udział 76 bezzębnych osób powyżej 60 roku życia, z których na wizytę kontrolną po 3 miesiącach zgłosiło się 66. Zbadano poczucie jakości życia związanej ze zdrowiem jamy ustnej przy użyciu kwestionariusza General Oral Health Assessment Index przed wykonaniem uzupełnień protetycznych i po 3-miesięcznym okresie adaptacji.

Wyniki. W ocenie jakości życia związanej ze zdrowiem jamy ustnej przed leczeniem protetycznym najniższą punktację pacjenci uzyskali w zakresie odczuwania problemów z żuciem pokarmów (Q2), zaniepokojenia stanem własnego uzębienia (Q9) i odczuwania dyskomfortu w czasie jedzenia (Q5). Po trzymiesięcznym okresie adaptacji najwyższy wzrost procentowy odnotowano w zakresie zadowolenia z wyglądu uzębienia (Q7), natomiast nadal ponad 10\% pacjentów odczuwało negatywny wpływ problemów ze spożywaniem pokarmów na życie codzienne (Q1, Q2, Q5).

Wnioski. Leczenie protetyczne pacjentów bezzębnych z zastosowaniem konwencjonalnych protez całkowitych znacząco poprawia poczucie jakości życia związanej ze zdrowiem jamy ustnej. Negatywny wpływ problemów z żuciem wpływających na dyskomfort jest obserwowany u ponad $10 \%$ badanych.

Słowa kluczowe: jakość życia związana ze zdrowiem jamy ustnej, pacjenci w wieku podeszłym, leczenie protetyczne, bezzębie.

\section{Introduction}

For many, the prolongation of human life implies struggles with senile diseases. Aging processes are irreversible, and their course may be modified by a number of diverse factors which influence the body throughout people's entire life. One of the main criteria in satisfactory aging is the maintenance of one's own, healthy and functional dentition. Oral health is a vital element of general health and a factor impacting one's quality of life [1]. Ac- 
cording to predictions, dental demands from older patients will continue to increase, not only due to the growing number of people in this age group but also as a result of variously caused dentition loss. As emphasized by Douglass, the challenges posed by a large group of elderly people suffering from mandibular and/or maxillary edentulism will continue to arise, and thus we ought to pay particular attention to educating young dentists regarding efficient complete prostheses [2].

The treatment of edentulous patients is a challenge for both doctors and patients, since for a number of the latter conventional, complete removable prostheses remain the sole possibility for reconstructing dentition loss.

One method to evaluate the efficiency of prosthetic rehabilitation is oral health related quality of life (OHRQoL) assessment. It is possible to evaluate the quality of life of older patients using a wide array of indicators and questionnaires. Among the main requirements set out for such research tools are reliability, validity, and susceptibility to ongoing changes (e.g. induced by the applied method of treatment). One of the most frequently used research tools in OHRQoL assessment is the General Oral Health Assessment Index.

\section{Material and methods}

The research group comprised edentulous patients from the Gerostomatology Clinic at the Poznań University of Medical Sciences, who reported to its medical centre in order to replace their used prostheses or have complete prostheses fixed for the first time. The examination involved 76 patients over 60 years of age. The two criteria which excluded prospective patients from the research were the impossibility of establishing meaningful contact with them, and dementia. Patients agreed to subject themselves to clinical and questionnaire tests, and were informed about the possibility of withdrawing from the research or refusing to answer some of the questions included in the questionnaire.

The questionnaire included the following categories: age, sex, place of residence, marital status, level of education, financial situation, oral health and general health self-assessment, satisfaction with oral cavity health condition and possible problems when masticating.

The next stage of the questionnaire tests involved filling out questionnaires assessing the patients' quality of life. OHRQoL was measured using the General Oral Hygiene Assessment Indicator (GOHAl) adapted to Polish by the authors of this paper [3].

GOHAl is an indicator used in measuring the quality of life, consisting of 12 questions. This tool enables researchers to assess functional problems reported by patients with regard to their oral cavity and the psychosocial impact of oral cavity diseases on everyday life, as well as the efficiency of dental treatment received by the examined patient [4]. This indicator is based on a patient-oriented definition of oral health, and evaluates the impact of oral health on three dimensions of the patient's quality of life:

- physical functionality (including the consumption of foods, speaking and swallowing),

- psychosocial functionality (including unease at one's oral health, dissatisfaction with one's appearance, avoidance of social contacts caused by oral health problems), and

- pain and discomfort (including medications taken to alleviate the pain).

Each question could be answered using a five-point Likert scale (where $5=$ never, $4=$ seldom, $3=$ sometimes, 2 = often, 1 = always). The results were calculated as the sum total of answers provided by the patient, and thus the maximum score in the test was 60 , while the minimum amounted to 12 points. The higher the score, the better the OHRQoL. Atchison and Dolan (1990) interpreted these scores as follows:

- between 57 and 60 points - high score, indicating good OHRQoL

- between 51 and 56 - average score, indicating moderate OHRQoL

- below 50 points - low score, indicating poor OHRQoL.

The patients who received their complete prostheses at the Gerostomatology Clinic were asked to report for check-ups at the end of the 3-month post-treatment period in order to examine their OHRQoL using GOHAl questionnaires. Respective OHRQoL aspects were carefully analysed in terms of their improvement / decline / invariability following prosthetic rehabilitation.

For the statistical analysis of the differences between the two groups of scores, the authors of this study turned to Wilcoxon's test. The adopted statistical significance value was established at $p=0.05$. SPSS v.14 was chosen as statistical software. The research was approved by the Bioethics Committee of the Poznan University of Medical Sciences (reg. no. 630/12).

\section{Results}

Among the 76 patients treated with complete prostheses, 66 reported back for their respective check-ups. Since no significant differences in social and demographic data were stated among the patients originally qualifying for the research and the group of patients returning for the posttreatment check-ups, subsequent analyses were restricted to the data procured from the 66 returning patients. Table 1 presents the general profile of the research group. The majority of the examined patients were women, individuals with secondary education who listed their financial status as average. 
With respect to OHRQoL assessment, the lowest scores were achieved in the following fields: mastication (Q2), unease at the state of one's dentition (Q9), and discomfort while eating (Q5). Following the three-month adaptation period, the highest percentage point increase was listed in terms of satisfaction with the appearance of dentition (Q7). A drop-off was observed with regard to the use of medications (Q8). Following the patients' prosthetic treatment, no vital statistical difference was stated with regard to questions concerning reductions in the consumption of foods due to problems with prosthetic restoration (Q1), pronunciation (Q4), and discomfort experienced by the patients (Q5). The above results are represented in Table 2.
Since the averages calculated based on the respective questions do not fully reflect the impact of a given issue on the patients' daily life, a focus was put on their experiences with regard to the negative effects of oral cavity diseases on the quality of life.

Table 3 presents the percentage breakdown of the patients who experienced negative effects of oral cavity diseases on the quality of life. This negative impact was calculated as the percentage of patients who answered "always" or "often" to certain GOHAl questionnaire questions (i.e. questions 1, 2, 4, 6, 8-12), also taking into account the percentage of patients responding "seldom" or "never" in opposite questions (i.e. questions 3, 5,

Table 1. Research group profile

Tabela 1. Charakterystyka grupy badawczej

\begin{tabular}{|c|c|}
\hline Average age (SD) & $74.80(6.5)$ \\
\hline Age span & $60-88$ \\
\hline \multicolumn{2}{|c|}{ Sex } \\
\hline Women/Men & $68.2 \% / 31.8 \%$ \\
\hline \multicolumn{2}{|c|}{ Education } \\
\hline Primary & $33.3 \%$ \\
\hline Secondary & $50.0 \%$ \\
\hline Higher & $16.7 \%$ \\
\hline \multicolumn{2}{|c|}{ Financial status } \\
\hline Poor & $19.7 \%$ \\
\hline Average & $48.5 \%$ \\
\hline Good/V. good & $31.8 \%$ \\
\hline \multicolumn{2}{|c|}{ General health self-assessment } \\
\hline Very poor, poor & $18.2 \%$ \\
\hline Average & $37.9 \%$ \\
\hline Good/V. good & $44.0 \%$ \\
\hline \multicolumn{2}{|c|}{ Oral health self-assessment } \\
\hline Very poor, poor & $30.3 \%$ \\
\hline Average & $25.8 \%$ \\
\hline Good/V. good & $43.9 \%$ \\
\hline \multicolumn{2}{|c|}{ Problems with mastication } \\
\hline Yes & $45.5 \%$ \\
\hline No & $54.5 \%$ \\
\hline
\end{tabular}

Table 2. GOHAl before prosthetic treatment and three months after its completion

Tabela 2. GOHAl przed leczeniem protetycznym i po 3-miesięcznym okresie adaptacji

\begin{tabular}{|c|c|c|c|c|c|c|c|c|}
\hline Question & Avg. before & Avg. after & Difference in score & Change (percent points) & Increase & Decrease & No difference & $p$ \\
\hline 1 & $3.8(1.2)$ & $4.0(1.0)$ & 0.2 & $5.3 \%$ & 19 & 9 & 38 & $\mathrm{p}=0.164$ \\
\hline 2 & $3.1(1.4)$ & $3.6(1.0)$ & 0.5 & $16.1 \%$ & 32 & 8 & 26 & $\mathrm{p}=0.000$ \\
\hline 3 & $4.1(1.5)$ & $4.6(0.7)$ & 0.5 & $12.2 \%$ & 21 & 1 & 44 & $\mathrm{P}=0.000$ \\
\hline 4 & $4.2(1.1)$ & $4.3(0.8)$ & 0.1 & $2.4 \%$ & 14 & 11 & 41 & $\mathrm{P}=0.528$ \\
\hline 5 & $3.5(1.4)$ & $3.7(0.9)$ & 0.2 & $5.7 \%$ & 24 & 18 & 24 & $\mathrm{P}=0.151$ \\
\hline 6 & $4.5(1.0)$ & $4.7(0.8)$ & 0.2 & $4.4 \%$ & 8 & 2 & 56 & $\mathrm{P}=0.038$ \\
\hline 7 & $3.7(1.2)$ & $4.5(0.9)$ & 0.8 & $21.6 \%$ & 37 & 6 & 23 & $\mathrm{P}=0.000$ \\
\hline 8 & $4.1(1.1)$ & $3.8(0.9)$ & -0.3 & $-7.3 \%$ & 8 & 26 & 32 & $\mathrm{P}=0.010$ \\
\hline 9 & $3.4(1.2)$ & $3.9(1.0)$ & 0.5 & $14.7 \%$ & 29 & 8 & 29 & $\mathrm{P}=0.001$ \\
\hline 10 & $3.6(1.4)$ & $4.0(1.1)$ & 0.4 & $11.1 \%$ & 24 & 7 & 35 & $\mathrm{P}=0.002$ \\
\hline 11 & $3.7(1.4)$ & $4.2(1.0)$ & 0.5 & $13.5 \%$ & 25 & 3 & 38 & $\mathrm{P}=0.000$ \\
\hline 12 & $4.1(1.3)$ & $4.6(0.7)$ & 0.5 & $12.2 \%$ & 21 & 0 & 45 & $\mathrm{P}=0.000$ \\
\hline
\end{tabular}


Table 3. Breakdown of negative effects for respective aspects of oral health-related quality of life before and after prosthetic treatment

Tabela 3. Porównanie negatywnych wpływów poszczególnych aspektów jakości życia związanej ze zdrowiem jamy ustnej przed i po leczeniu protetycznym

\begin{tabular}{|l|c|c|}
\hline \multicolumn{1}{|c|}{ GOHAl } & $\begin{array}{c}\text { Before } \\
\text { treatment }\end{array}$ & $\begin{array}{c}\text { After } \\
\text { treatment }\end{array}$ \\
\hline Q1. Limit the kinds of food & $19.7 \%$ & $10.6 \%$ \\
\hline Q2. Trouble biting or chewing & $42.4 \%$ & $13.6 \%$ \\
\hline Q3. Able to swallow comfortably & $21.2 \%$ & $1.5 \%$ \\
\hline Q4. Unable to speak clearly & $9.1 \%$ & $1.5 \%$ \\
\hline Q5. Able to eat without discomfort & $28.8 \%$ & $10.6 \%$ \\
\hline Q6. Limit contact with people & $7.6 \%$ & $4.5 \%$ \\
\hline Q7. Pleased with look of teeth & $24.2 \%$ & $6.1 \%$ \\
\hline Q8. Used medication to relieve the pain & $12.1 \%$ & $4.5 \%$ \\
\hline Q9. Worried about teeth, gums or dentures & $27.3 \%$ & $6.1 \%$ \\
\hline $\begin{array}{l}\text { Q10. Self-conscious of teeth, gums or } \\
\text { dentures }\end{array}$ & $22.7 \%$ & $6.1 \%$ \\
\hline $\begin{array}{l}\text { Q11. Uncomfortable eating in front of } \\
\text { others }\end{array}$ & $22.7 \%$ & $4.5 \%$ \\
\hline Q12. Sensitive to hot, cold or sweet foods & $13.6 \%$ & $1.5 \%$ \\
\hline
\end{tabular}

Table 4. Breakdown of patient scores before and after prosthetic treatment with regard to respective GOHAl questionnaire score brackets.

Tabela 4. Porównanie wyników pacjentów przed i po leczeniu protetycznym z uwzględnieniem odpowiednich przedziałów punktowych kwestionariusza GOHAI

\begin{tabular}{|l|c|c|c|c|}
\hline \multirow{2}{*}{ Patient profile } & \multirow{2}{*}{$\mathrm{N}$} & \multicolumn{3}{|c|}{ GOHAI Score } \\
\cline { 3 - 5 } & & $\begin{array}{c}<50 \\
\text { Low score }\end{array}$ & $\begin{array}{c}51-56 \\
\text { Average score }\end{array}$ & $\begin{array}{c}57-60 \\
\text { High score }\end{array}$ \\
\hline Patients before prosthetic treatment & 66 & $62.1 \%$ & $31.9 \%$ & $6 \%$ \\
\hline Patients after prosthetic treatment & 66 & $43.9 \%$ & $44.1 \%$ & $12 \%$ \\
\hline
\end{tabular}

and 7). It ought to be noted that, in spite of the implemented prosthetic rehabilitation, over $10 \%$ of the patients continued to experience negative reactions with regard to certain aspects in the consumption of foods (Q1, Q2, Q5).

The final component in the analysis of the GOHAI scores before and after prosthetic treatment was the comparison of the scores according to Atchinson and Dolan's interpretation (see Table 4). The presented table indicates that, despite the post-treatment improvement in the GOHAI scores among the patients treated by the Gerostomatology Clinic, over $40 \%$ of the examined patients remained in the bottom tier of OHRQoL.

\section{Discussion}

It might seem that the advancement of civilization would find its reflection in a growing awareness of oral health. Unfortunately, the latest epidemiological studies on retired Polish citizens demonstrate the great degree of demand for dental treatment in this group. While in 1998 edentulism was observed in $34.7 \%$ of patients aged $65-74$, these values increased to $41.6 \%$ in 2002 and $43.9 \%$ in 2009 , respectively. Also considered in the cited studies was the mastication function, adopting a minimum of 20 natural or artificial teeth in functional contact. Thus, 1998 saw the preservation rate for the mastication function in $70.1 \%$ of the examined patients, with the number dropping to $69.4 \%$ in 2002, and further down to $49.6 \%$ in 2009 [5]. The above trends may lead us to conclude that Poland lacks a proper health policy aimed at the elderly and focusing on the preservation of oral health. Such a policy should take into consideration the increasing life expectancy rates, which calls for greater attention to prevention and treatment as well as resulting in the improvement of its quality among older patients.

To assess OHRQoL, the authors of this study employed the commonly used General Oral Health Assessment Index (GOHAI). Although the Oral Health Impact Profile (OHIP) remains the more popular questionnaire in this regard, having been adopted in a wide range of research, it was not chosen in this case for several reasons [6]. Comparative studies on the GOHAI and OHIP-14 questionnaires stated a lesser degree of floor effects in the former indicator [7]. GOHAl's superior sensitivity, both in terms of mastication efficiency changes 
along with its prevalence where the identification of oral cavity functionality is concerned, favoured its application [8]. Also significant was the fact that the GOHAl indicator was originally created to examine the impact of oral cavity diseases on the quality of life of older patients [4].

As manifested by the exact analysis of scores in the questionnaires filled out by the patients of the Gerostomatology Clinic, it was mastication problems and discomfort while eating (Q2, Q5) that had the most negative impact on their OHRQoL. The possibility to consume foods in a completely uninhibited manner cannot be underestimated as a factor determining the patients' quality of life and their overall well-being. The ongoing loss of dentition entails a diminished ability to masticate food bites, and removable prostheses, even top quality ones, cannot fully compensate for the substantial loss of chewing efficiency. As pointed out by Fueki, mastication problems constitute the most significant change in terms of its influence on oral health related quality of life [9]. Additionally, Demers has proved that the problem of chewing food affects approximately $50 \%$ of complete prosthesis users [10].

Another issue which demonstrated the highly unfavourable impact on OHRQoL was the question about the level of patients' satisfaction with the appearance of their teeth or prostheses (Q7). This problem concerned $24.2 \%$ of the patients reporting at the Gerostomatology Clinic for prosthetic restoration. Our observations furthered the point made by Hassel, who claimed the appearance of dentition constitutes a vital factor among the elderly [11]. On the other hand, Komangamine lists proper retention of the lower prosthesis and satisfaction with the appearance of artificial dentition as the two most important factors which determine the quality of life among elderly patients [12]. It was in this very aspect that the authors of this study observed the highest percentage point increase when examining the post-treatment questionnaires.

Unfavourable changes, i.e. deteriorations in pre-treatment scores, were observed with regard to question 8 which concerned the use of medications likely to alleviate the pain experienced by users of new prostheses. The assessment of the impact of prosthetic treatment on OHRQoL indicated an improvement in GOHAl scores, as well as a diminishment in the negative influence of dentition deficiencies on OHRQoL. Similar research (conducted on smaller research groups) devoted to the impact of prosthetic treatment on GOHAI scores was conducted by Shigli, who analysed a group of 35 patients; and Veyrune, who examined 26 patients [13, 14]. In both studies, as in ours, an improvement was found in the average questionnaire scores following the prosthetic treatment of edentulous patients. Nonetheless, it ought to be emphasized that in spite of the improvement in the general GOHAl scores, over $40 \%$ of older patients scored below 50 points, which corresponds to a poor sense of OHRQoL. Additionally, $13.6 \%$ of the edentulous patients continued to experience daily mastication problems when chewing gum (Q2). As per Gjengedal and Awad, edentulous patients who failed to observe a significant upturn in OHRQoL following the fitting of conventional complete prostheses ought to turn to mandibular overdenture prostheses supported with intraosseous implants $[15,16]$. Such a method of prosthetic rehabilitation should largely improve OHRQoL among completely edentulous patients, particularly those suffering from toothless mandible.

\section{Conclusions}

Prosthetic treatment of edentulous patients using conventional complete prostheses significantly improves their OHRQoL. However, it seems impossible to fully eliminate the negative by-effects caused by mastication problems and, consequently, the feeling of discomfort experienced by over $10 \%$ of the examined patients.

\section{Acknowledgements}

\section{Conflict of interest statement}

The authors declare that there is no conflict of interest in the authorship or publication of contribution.

\section{Funding sources}

There are no sources of funding to declare.

\section{References}

[1] Berkey D, Berg R. Geriatric oral health issues in the United States. Int Dent J. 2001;51(3 Suppl.):254-264.

[2] Douglass CW, Shih A, Ostry L. Will there be a need for complete dentures in the United States in 2020? J Prosthet Dent. 2002;87(1):5-8.

[3] Gałczyńska-Rusin M, Koczorowski R, Sielska J. Linguistic adaptation and validation of the Polish version of the General Oral Health Assessment Index (GOHAI). J Stoma. 2014;67(2):152-165.

[4] Atchison KA, Dolan TA. Development of the Geriatric Oral Health Assessment Index. J Dent Educ. 1990;54:680687.

[5] Jodkowska E. The condition of dentition status of adults polish citizens in years 1998-2009. Przegl Epidemiol. 2010;64:571-576.

[6] Slade GD, Spencer AJ. Development and evaluation of the Oral Health Impact Profile. Community Dent Health. 1994;11:3-11.

[7] Hassel AJ, Steuker B, Rolko C, Keller L, Rammelsberg $P$, Nitschke I. Oral health-related quality of life of elderly Germans - comparison of GOHAI and OHIP-14. Community Dent Health. 2010;27:242-247.

[8] Ikebe K, Hazeyama T, Enoki K, Murai S, Okada T, Kagawa R, Matsuda K, Maeda Y. Comparison of GOHAl and OHIP-14 measures in relation to objective values of oral function in elderly Japanese. Community Dent Oral Epidemiol. 2012;40(5):406-414.

[9] Fueki K, Yoshida E, Igarashi Y. A structural equation model relating objective and subjective masticatory function and oral health-related quality of life in patients with removable partial dentures. Journal of Oral Rehabilitation. 2011;38:86-94. 
[10] Demers M, Bourdages J, Brodeur JM, Benigeri M. Indicators of masticatory performance among elderly complete denture wearers. J Prosthet Dent. 1996:75(2):188-193.

[11] Hassel AJ, Wegener I, Rolko C, Nitschke I. Self-rating of satisfaction with dental appearance in an elderly German population. Int Dent J. 2008;58(2):98-102

[12] Komagamine Y, Kanazawa M, Kaiba Y, Sato Y, Minakuchi S, Sasaki Y. Association between self-assessment of complete dentures and oral health related quality of life. J Oral Rehabil. 2012;39(11):847-857.

[13] Shigli K, Hebbal M. Assessment of changes in oral health-related quality of life among patients with complete denture before and 1 month post-insertion using $\mathrm{Ge}$ riatric Oral Health Assessment Index. Gerodontology. 2010;27(3):167-173.

[14] Veyrune JL, Tubert-Jeannin S, Dutheil C, Riordan PJ. Impact of new prostheseson the oral health related quality of life of edentulous patients. Gerodontology. 2005;22(1):3-9.

[15] Gjengedal H, Berg E, Gronningsaeter AG, Dahl L, Malde MK, Boe OE, Trovik TA. The influence of relining or implant retaining existing mandibular dentures on health-related quality of life: a 2-year randomized study of dissatisfied edentulous patients. Int J Prosthodont. 2013;26(1):68-78.
[16] Awad MA, Lund JP, Shapiro SH, Locker D, Klemetti E, Chehade A, Savard A, Feine JS. Oral health status and treatment satisfaction with mandibular implant overdentures and conventional dentures: a randomized clinical trial in a senior population. Int J Prosthodont. 2003;16(4):390-6.

Acceptance for editing: 2016-04-28 Acceptance for publication: 2016-05-06

\section{Correspondence address:}

Małgorzata Gałczyńska-Rusin

Poznan University of Medical Sciences

70 Bukowska Street, 60-812 Poznan, Poland

phone: +48 607118364

fax: +48 618547094

e-mail: m.galczynskarusin@gmail.com 